\title{
PREFACE TO THE 1985 EDITION
}

The pages that follow represent the lectures given under the same title at the University of California, Berkeley, in the fall of 1982. The Preface, notes, and two appendices have been added; apart from these, material changes have been slight.

Opinions on the value of Pausanias' work still diverge. To some, he seems muddleheaded; to others, a most reliable guide. The strongest accusations against him have for some time been satisfactorily answered and are no longer a real issue. There is, nonetheless, still much current prejudice against him and also, among literary critics, a tendency to neglect him. ${ }^{1}$ A low esteem for postclassical authors in general may have contributed more to this neglect than the assessment of

'Ed. Norden, in his monumental Antike Kunstprosa, has no room for a discussion of Pausanias; he gives him just one sentence (which does not even mention his name): "Ein Grieche registriert die Monumente der Vorzeit weniger aus künstlerischem als aus antiquarischem Interesse: er ist dadurch eine unserer wichtigsten Quellen für Religionsaltertümer geworden" (vol. 1, 3d ed. [Leipzig and Berlin 1915], 345). M. P. Nilsson, where he discusses Greek religion as reflected in the literature of the empire, has sections on Babrius, Lucian, Aristides, Philostratus, Aelianus, Heliodorus, and Nonnus, but nothing on Pausanias (Geschichte der griechischen Religion, vol. 2 [Munich 1950], 535-46; 3d ed. [1974], 558-69). In their introduction to a volume devoted to Greek literature written under the empire the editors especially regret the absence of essays "on Nonnus . . . or his many successors; ... on Philostratus, the eminent sophists, Aelian, Quintus of Smyrna, the other novelists, the literary criticism of philosophers, Plutarch, Oppian, and many others who well deserve to be read ..." (J.J. Winkler and G. Williams, YCS 27 [1982]: vii-viii) - again no mention of Pausanias, who could easily compete with most of those named. Finally, the recent collection Ancient Writers: Greece and Rome, edited by T. Luce (2 vols. [New York 1982]), has, among some fifty authors, no corner for Pausanias. 
Pausanias' individual ability as a writer. If it is true of all these writers that "the greatest need . . . is for sustained analyses of the fundamental quality of literature written in the shadow of a . . classical past," ${ }^{2}$ Pausanias most definitely deserves a fresh study. The most pressing need, it has been stated long ago, is for an interpretation of Pausanias' work that does not lose sight of the whole for the sake of the particulars. ${ }^{3}$ The present volume is meant to be a modest contribution toward this goal.

The English quotations from Pausanias' text are taken from James G. Frazer's translation of 1898 , whose literary quality far outweighs anything that might seem out of fashion in expression or in spelling of ancient names. References with Roman numerals always refer to the books of Pausanias.

My obligations are numerous and deeply felt. For the generous invitation to do these lectures I am obliged to the members of the Department of Classics at the University of California, Berkeley, and to them and their chairman, Charles Murgia, as well as to many colleagues in other departments, for their kindness, assistance, and hospitality. They all made our stay in the Bay Area a delightful and unforgettable experience.

In the preparation of the book my greatest debt is to Dr. Alfred S. Bradford, Jr., for many good suggestions and for a very thorough revision of my English draft. I am also most grateful to Mrs. Sandra S. Lafferty of the Institute for Advanced Study for her meticulous preparation of the typescript and to Mrs. Doris Kretschmer and her staff at the Press for all the care they provided during the editorial process. Finally, I wish to acknowledge with gratitude the kindness of all those who authorized me to reproduce photographs, maps, or drawings: American School of Classical Studies, Athens (figs. 25, 26, 30); Archaiologike Hetaireia, Athens (figs. 8a, 9-11, 13, 14, 16, 23); A. S. Bradford (fig. 8b); Deutsches Archäologisches Institut, Abteilung Athen (figs. 15, 17-19, 28, 29, 31); Deutsches Archäologisches Institut, Abteilung Istanbul (figs. 12, 20); Ecole Française d'Archéologie, Athens (fig. 1); Alison Frantz (fig. 22); Pantos Pantos (figs. 3-5); R. Schoder, SJ (figs. 6, 7); A. F. Stewart (fig. 34).

\footnotetext{
${ }^{2}$ Winkler and Williams (above, n. 1), p. viii.

${ }^{3}$ Regenbogen, p. 1095: "Was für das gesamte Werk des P. am dringendsten vonnöten, aber nicht immer leicht ist, ist die Interpretation auch des Einzelnen aus dem Ganzen heraus. Es ist fraglich, ob in unserer Zeit das noch einmal geleistet werden wird."
} 